\title{
Hydro-Chemical Characterization of Glacial Melt Waters Draining from Langtang Valley, Nepal
}

\author{
Anisha Tuladhar*, Rijan Bhakta Kayastha, Smriti Gurung, Ahuti Shrestha \\ Department of Environmental Science and Engineering, Kathmandu University, Dhulikhel, Nepal \\ Email: ${ }^{*}$ anishatuladhr@gmail.com
}

Received 22 February 2015; accepted 5 June 2015; published 11 June 2015

Copyright (C) 2015 by authors and Scientific Research Publishing Inc.

This work is licensed under the Creative Commons Attribution International License (CC BY). http://creativecommons.org/licenses/by/4.0/

(c) (i) Open Access

\section{Abstract}

A detailed analytical study of the physico-chemical parameters of melt water draining from glaciers of Langtang Valley with an elevation ranging from $1395 \mathrm{~m}$ a $\mathrm{l}$ to $4200 \mathrm{~m}$ a $\mathrm{s}$ in Rasuwa district, Nepal was carried out in order to study the seasonal and altitudinal variation in hydro-chemistry along the Langtang River and glacial melts from the Lirung and the Khimsung Glaciers. The study was carried out during 6 - 10 April and 30 June-3 July, 2014 at 11 sites. A total of 22 composite samples were collected. The concentration of cations and anions of the Langtang Valley were found in the order $\mathrm{Ca}^{2+}>\mathrm{K}^{+}>\mathrm{Na}^{+}>\mathrm{Mg}^{2+}$ and $\mathrm{HCO}_{3}^{-}>\mathrm{Cl}^{-}>\mathrm{SO}_{4}^{2-}>\mathrm{NO}_{3}^{-}>\mathrm{TP}-\mathrm{PO}_{4}^{3-}$, respectively. Significant seasonal variation in electrical conductivity (EC), turbidity, dissolved oxygen (DO), calcium (Ca), sodium ( $\mathrm{Na}$ ), magnesium (Mg), chloride ( $\mathrm{Cl}$ ), sulphate $\left(\mathrm{SO}_{4}\right)$ and total phosphorus (TP$\mathrm{PO}_{4}$ ) and altitudinal variation in EC, total dissolved solids (TDS), DO and Na was found out. The concentrations of the heavy metals ( $\mathrm{As}, \mathrm{Al}, \mathrm{Mn}, \mathrm{Zn}, \mathrm{Cd}, \mathrm{Cr}$ ) were below the detection limit except Fe $(0.5$ to $18.1 \mathrm{mg} / \mathrm{l})$, which was highly variable. Calcium carbonate weathering was found out to be the major source of dissolved ions in the region. The elemental ratios $(\mathrm{Ca} / \mathrm{Si}$ and $\mathrm{K} / \mathrm{Na})$ were typical of glacial melt water and the low $\mathrm{Na} / \mathrm{Cl}$ and $\mathrm{K} / \mathrm{Cl}$ ratios indicated major contribution from atmospheric precipitation to the observed dissolved ions of melt waters. The study showed an increase in the concentration of cations as compared to previous studies, which could be attributed to increasing weathering rates due to temperature increase. Elevated concentration of $\mathrm{NO}_{3}$ and TP- $\mathrm{PO}_{4}$ compared to previous studies show the effect of human impact in the region. Differences in the melt water composition between the debris covered and clean type glacier was found out.

\section{Keywords}

Hydro-Chemistry, Langtang River, Weathering Process, Glacier Melt Water

\footnotetext{
${ }^{*}$ Corresponding author.
}

How to cite this paper: Tuladhar, A., Kayastha, R.B., Gurung, S. and Shrestha, A. (2015) Hydro-Chemical Characterization of Glacial Melt Waters Draining from Langtang Valley, Nepal. Journal of Water Resource and Protection, 7, 605-613. 


\section{Introduction}

Glaciers form one of the components of the hydrological budget playing an important role in buffering stream flow [1], acting as water storage over a range of temporal and spatial scales [2] [3] and providing water to downstream users and communities during periods of low precipitation as well [4] [5]. The Himalayan region, encompassing the Hindu Kush mountains and the Tibetan Plateau, spanning Afghanistan, Bhutan, China, India, Myanmar, Nepal, and Pakistan are rich in glaciers [6].

Melt waters from mountain glaciers of the Himalayas are one of the dominant water resources for Nepal along with rainfall and ground water [7] on which the country depend for drinking water, irrigation and hydropower [8]. However, anthropogenically induced climate change causing glacial retreats can have serious impacts on hydrological cycles resulting in decrease in water resources [9] [10], quality and quantity. A recent study in the Himalayas has indicated an annual increase in the nitrogen and phosphorous concentration in the high altitude river system [11]. Moreover, the growing demand for freshwater in downstream stretches and the geological setting has made the hydro chemical study of Himalayan glaciers highly imperative [12]. Therefore, chemical characteristic of melt waters from the glaciers is extremely important to find out the weathering reactions, anthropogenic and climate change impacts on the water resources which can contribute in entire river basin management.

\section{Materials and Methods}

\subsection{Study Area}

The study was carried out in the Langtang River basin which lies in the Langtang National Park, Nepal. It is a sub-basin of Ganges River basin and lies in between the longitudes $85^{\circ} 15^{\prime} \mathrm{E}$ to $86^{\circ} \mathrm{E}$ and latitude $28^{\circ} \mathrm{N}$ to $28^{\circ} 20^{\prime} \mathrm{N}$. The Lirung Glacier is the fourth largest debris-covered glacier in this valley [13] with a basin area of $13.8 \mathrm{~km}^{2}$ whereas; the Khimsung glacier is the clean type glacier and is a smaller watershed glacier located at the right bank side of the Langtang River with an area of $6.6 \mathrm{~km}^{2}$ [14].

\subsection{Sampling and Analysis}

Water samples for the analysis of major cations (Ca, Mg, $\mathrm{Na}, \mathrm{K})$, major anions $\left(\mathrm{HCO}_{3}, \mathrm{Cl}, \mathrm{SO}_{4}, \mathrm{NO}_{3}, \mathrm{TP}_{-} \mathrm{PO}_{4}\right)$, heavy metals (Fe, As, Al, Mn, Zn, Cd, Cr) and total silica ( $\mathrm{Si}$ ) were sampled in Langtang region in pre-monsoon season (6-10 April 2014) and monsoon season (30 June-3 July 2014) at 11 sites. Therefore, a total of 22 composite samples were collected and analyzed for different parameters. The samples were collected, preserved and analyzed following standard procedures [15] at Department of Environmental Engineering and Science (DESE laboratory) at Kathmandu University and Environment and public health organization (ENPHO laboratory) within 2 weeks of sample collection. Parameters with extremely low stability such as conductivity (EC), bicarbonate $\left(\mathrm{HCO}_{3}\right)$ and $\mathrm{pH}$ were determined on the field using different analysis techniques.

One way ANOVA and Mann Whitney tests were performed to find out the seasonal and altitudinal variations of the parameters using SPSS 15.0 and Rock Works 16 is used to create the Piper plot diagram [16] to find out the dominant weathering mechanism of the basin (Table 1, Figure 1).

\section{Results and Discussion}

The chemical characteristics of glacial melt waters draining from Langtang Valley are given in Table 2. The charge balance error $\left(\mathrm{TZ}^{+}-\mathrm{TZ}^{-} / \mathrm{TZ}^{+}+\mathrm{TZ}^{-} \times 100\right)$ [17], were $\sim 10 \%$ confirming the reliability and quality of the analytical results. The average $\mathrm{pH}$ indicates the alkaline nature of the surface waters of the Langtang Valley. Previous studies in the Langtang Valley [18] [19] have also shown the $\mathrm{pH}$ within the same range indicating that the surface waters are still characteristically well buffered. The average conductivity showed a high degree of variability ranging from $8.67 \mu \mathrm{S} \cdot \mathrm{cm}^{-1}$ (KP, July 2014) to $163.33 \mu \mathrm{S} \cdot \mathrm{cm}^{-1}$ (L6, April 2014). Mann Whitney test showed that the conductivity is significantly $(\mathrm{p}<0.05)$ lower during monsoon and also at higher altitude.

Similarly, Mann Whitney test revealed a significant variation of TDS with respect to altitude $(p<0.05)$ with higher values in lower altitude ranging from 4 ppm (KO, July 2014) to 80.33 ppm (L6, April 2014); whereas turbidity showed a significant variation with season $(\mathrm{p}<0.05)$ with higher values during monsoon. Decrease in TSS and turbidity with distance from glaciers was observed during pre-monsoon season, where they were higher 
Table 1. Location of sampling stations.

\begin{tabular}{cccc}
\hline S.N. & Location & Sample Code & Altitude (m a s l) \\
\hline 1. & Khimsung Pond & KP & 4200 \\
2. & Khimsung Outlet & KO & 4163 \\
3. & Lirung Pond & LP & 3982 \\
4. & Lirung Outlet & LO & 3883 \\
5. & Point of contact between Lirung and Khimsung Glacier & LK & 3875 \\
6. & Helambu Bridge (Langtang River before Kyanjing) & L1 & 3779 \\
7. & DHM Station/Kyanjing Hydrostation & L2 & 3646 \\
8. & Riverside & L3 & 2757 \\
9. & Welcome Bridge (Before Bamboo) & L4 & 2143 \\
10. & Tiwari, New Bridge (Before Syaphrubesi) & L5 & 1547 \\
11. & Chilimi Hydropower (After Syaphrubesi) & L6 & 1395 \\
\hline
\end{tabular}

Table 2. Chemical characteristics of langtang valley meltwaters. (Unit: $\mathrm{EC}$ in $\mu \mathrm{S} \cdot \mathrm{cm}^{-1}$; TDS in ppm; Turbidity in NTU; DO to $\mathrm{Cd}$ in $\mathrm{mg} \cdot \mathrm{L}^{-1}$; $\mathrm{TZ}^{+}, \mathrm{TZ}^{-}$in $\mathrm{meq} \cdot \mathrm{L}^{-1}$ ).

\begin{tabular}{|c|c|c|c|c|}
\hline Parameter & Max & Min & Average & SD \\
\hline $\mathrm{pH}$ & 8.30 & 7.70 & 8.01 & 0.16 \\
\hline EC & 163.33 & 8.67 & 65.47 & 38.36 \\
\hline TDS & 80.33 & 4.00 & 27.45 & 15.99 \\
\hline DO & 11.43 & 7.70 & 9.60 & 1.10 \\
\hline Turbidity & 112.33 & 2.00 & 33.42 & 36.17 \\
\hline TSS & 584.00 & 18.00 & 141.18 & 145.37 \\
\hline $\mathrm{Ca}^{2+}$ & 25.70 & 2.24 & 10.77 & 5.53 \\
\hline $\mathrm{Mg}^{2+}$ & 4.46 & 0.25 & 1.64 & 1.27 \\
\hline $\mathrm{Na}^{+}$ & 5.30 & 0.50 & 1.89 & 1.26 \\
\hline $\mathrm{K}^{+}$ & 6.00 & 0.80 & 2.08 & 1.48 \\
\hline $\mathrm{HCO}_{3}^{-}$ & 78.10 & 12.93 & 36.63 & 15.15 \\
\hline $\mathrm{CO}_{3}^{2-}$ & 38.40 & 6.36 & 18.01 & 7.45 \\
\hline $\mathrm{SO}_{4}^{2-}$ & 19.00 & 0.40 & 4.97 & 5.31 \\
\hline $\mathrm{Cl}^{-}$ & 12.00 & 5.00 & 8.24 & 2.26 \\
\hline $\mathrm{NO}_{3}^{-}$ & 7.50 & 1.46 & 3.06 & 1.67 \\
\hline TP- $\mathrm{PO}_{4}^{3-}$ & 0.80 & 0.05 & 0.29 & 0.24 \\
\hline $\mathrm{Si}$ & 13.10 & 1.80 & 5.14 & 2.98 \\
\hline $\mathrm{Fe}$ & 18.10 & 0.50 & 5.88 & 5.54 \\
\hline As & 0.01 & 0.01 & 0.01 & 0.00 \\
\hline Mn & 0.20 & 0.05 & 0.13 & 0.07 \\
\hline $\mathrm{Zn}$ & 0.10 & 0.06 & 0.08 & 0.03 \\
\hline $\mathrm{Al}$ & 0.20 & 0.05 & 0.11 & 0.07 \\
\hline $\mathrm{Cd}$ & 0.02 & 0.02 & 0.02 & 0.00 \\
\hline $\mathrm{TZ}^{+}$ & 1.48 & 0.41 & 0.81 & 0.29 \\
\hline $\mathrm{TZ}^{-}$ & 1.42 & 0.73 & 0.99 & 0.21 \\
\hline
\end{tabular}




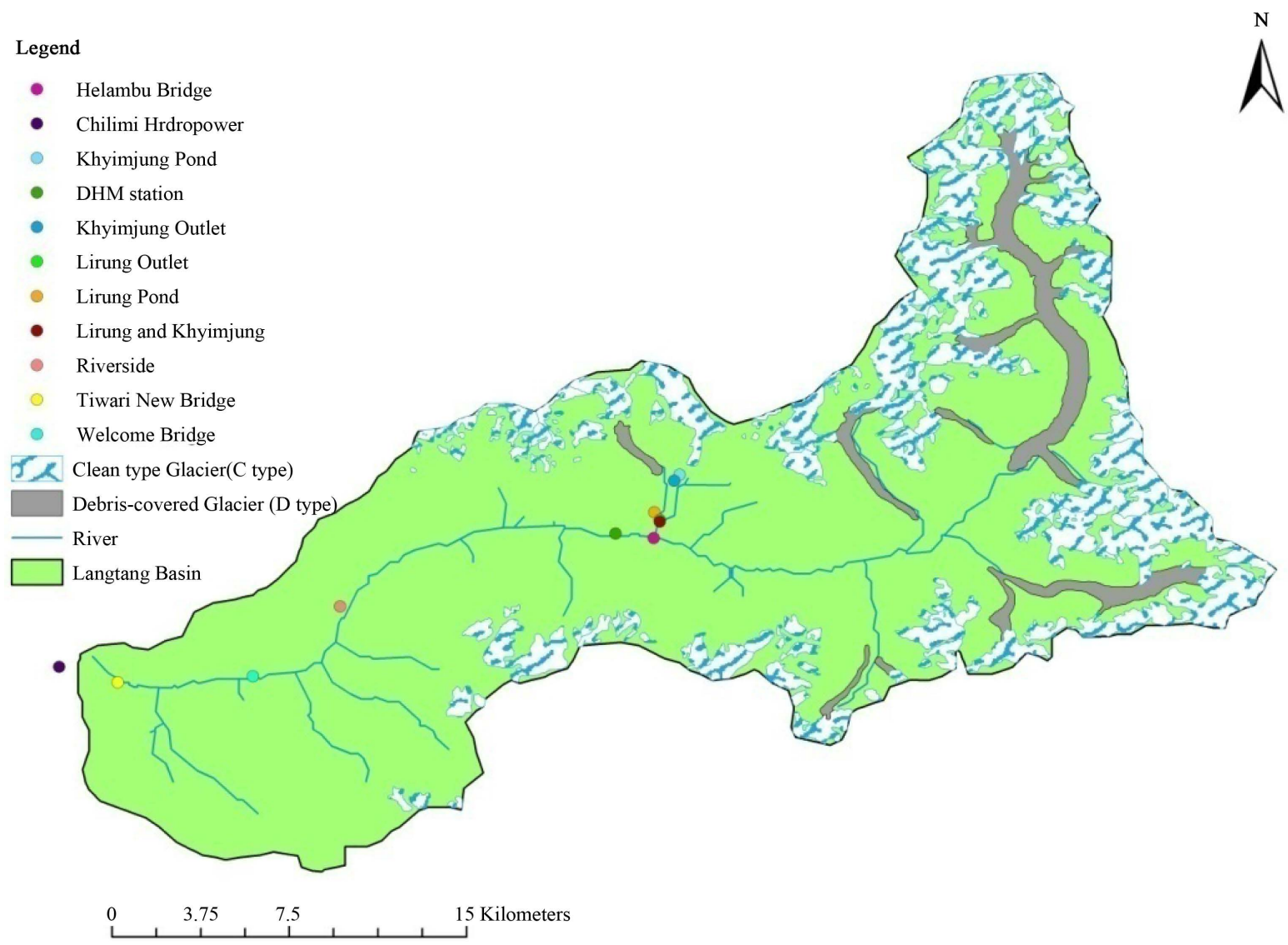

Figure 1. Map of langtang valley showing sampling station.

near glaciers, with highest at the KO (24.67 NTU and $180 \mathrm{mg} \cdot \mathrm{L}^{-1}$, respectively) attributing to glacial silt, and lowest at L5 (4 NTU and $40 \mathrm{mg} \cdot \mathrm{L}^{-1}$, respectively).

The DO ranged from $7.7 \mathrm{mg} \cdot \mathrm{L}^{-1}$ (LP, April 2014) to $11.43 \mathrm{mg} \cdot \mathrm{L}^{-1}$ (L4, April 2014). One way ANOVA revealed a significant seasonal and altitudinal variation in DO $(\mathrm{p}<0.05)$. DO was significantly higher during Monsoon and at lower altitudes. The decrease in DO during the pre-monsoon season is due to decrease in water levels resulting in less mixing of air with water [20]. The decrease in atmospheric pressure with increasing altitude, and the resulting low partial pressures of oxygen and carbon dioxide are recognized as possible limiting factors for low DO at high altitudes [21] [22].

The concentration of the major cations in the Langtang valley were found out in the order of $\mathrm{Ca}^{2+}>\mathrm{K}^{+}>\mathrm{Na}^{+}>$ $\mathrm{Mg}^{2+}$. Ca was significantly $(\mathrm{p}<0.05)$ lower during monsoon season; whereas Na was significantly $(\mathrm{p}<0.05)$ lower during monsoon season and at higher altitude. The dominance of the major anions in the Langtang valley was found out in the order of $\mathrm{HCO}_{3}^{-}>\mathrm{Cl}^{-}>\mathrm{SO}_{4}^{2-}>\mathrm{NO}_{3}^{-}>\mathrm{TP}-\mathrm{PO}_{4}^{3-} \cdot \mathrm{SO}_{4}$ was found out to be significantly $(\mathrm{p}<0.05)$ higher during pre-monsoon season; whereas $\mathrm{Cl}$ and TP- $\mathrm{PO}_{4}$ were significantly $(\mathrm{p}<0.05)$ higher during monsoon season. $\mathrm{HCO}_{3}$ was significantly $(\mathrm{p}<0.05)$ higher at lower altitude. Significant seasonal variation $(\mathrm{p}<0.05)$ in heavy metals was not seen, except for $\mathrm{Fe}$, with higher concentrations during monsoon. Fe ranged from $0.5 \mathrm{mg} \cdot \mathrm{L}^{-1}$ (L1, April 2014) to $18.10 \mathrm{mg} \cdot \mathrm{L}^{-1}$ (L1, July 2014).

Weathering of rocks is the dominant mechanism controlling the hydro-chemistry of drainage basins which occur when water flows at the ice-rock interface [23]. The variation in the conductivity and most of the major ions, with higher values in the lower elevation sites (Figure 2) may be due to rapid dissolution, higher temperature, high erosion, mixing of tributaries and enhanced weathering along the distance downstream.

The piper plot diagram (Figure 3) showed that the majority of samples fell into the category of Ca- $\mathrm{HCO}_{3}$ and $\mathrm{Mg}-\mathrm{HCO}_{3}$ types of water indicating Ca dominance and weak acids $\left(\mathrm{HCO}_{3}\right.$ and $\left.\mathrm{CO}_{3}\right)$ dominance over strong acids $\left(\mathrm{SO}_{4}\right.$ and $\left.\mathrm{Cl}\right)$. Cation and anion analysis also showed that $\mathrm{Ca}$ and $\mathrm{HCO}_{3}$ are indeed the most dominant cation 


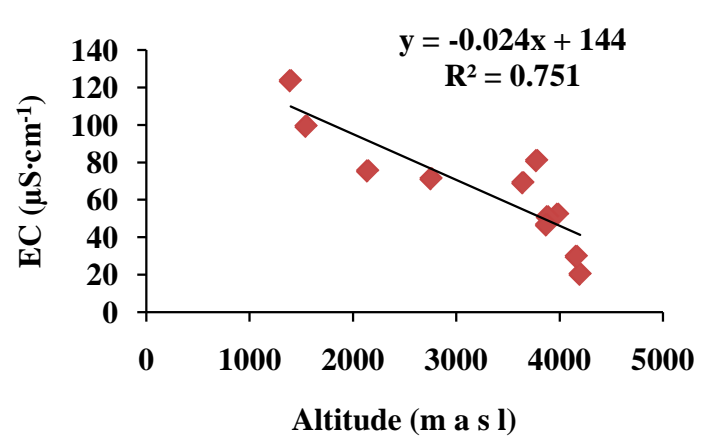

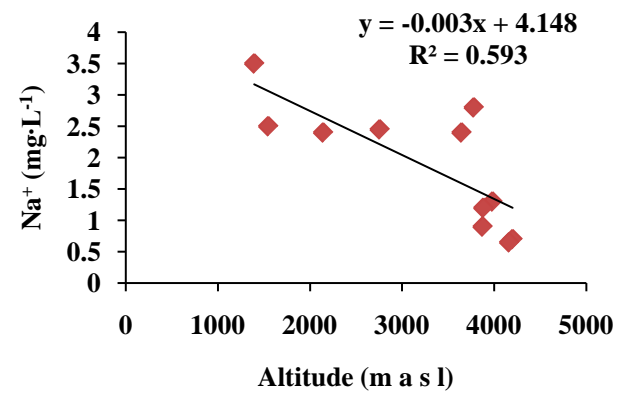

(b)

(a)

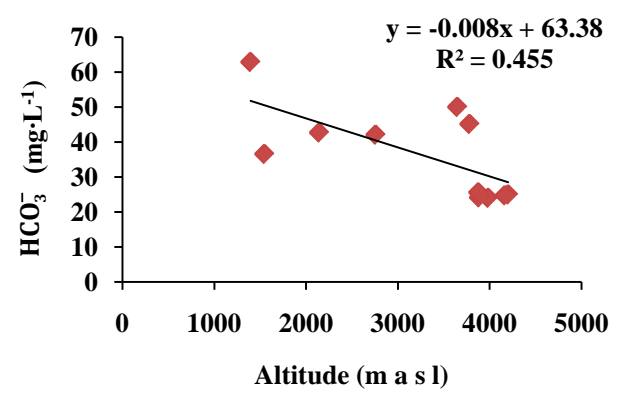

(c)

Figure 2. (a) Relationship between conductivity and altitude; (b) Relationship between sodium and altitude; (c) Relationship between bicarbonate and altitude.

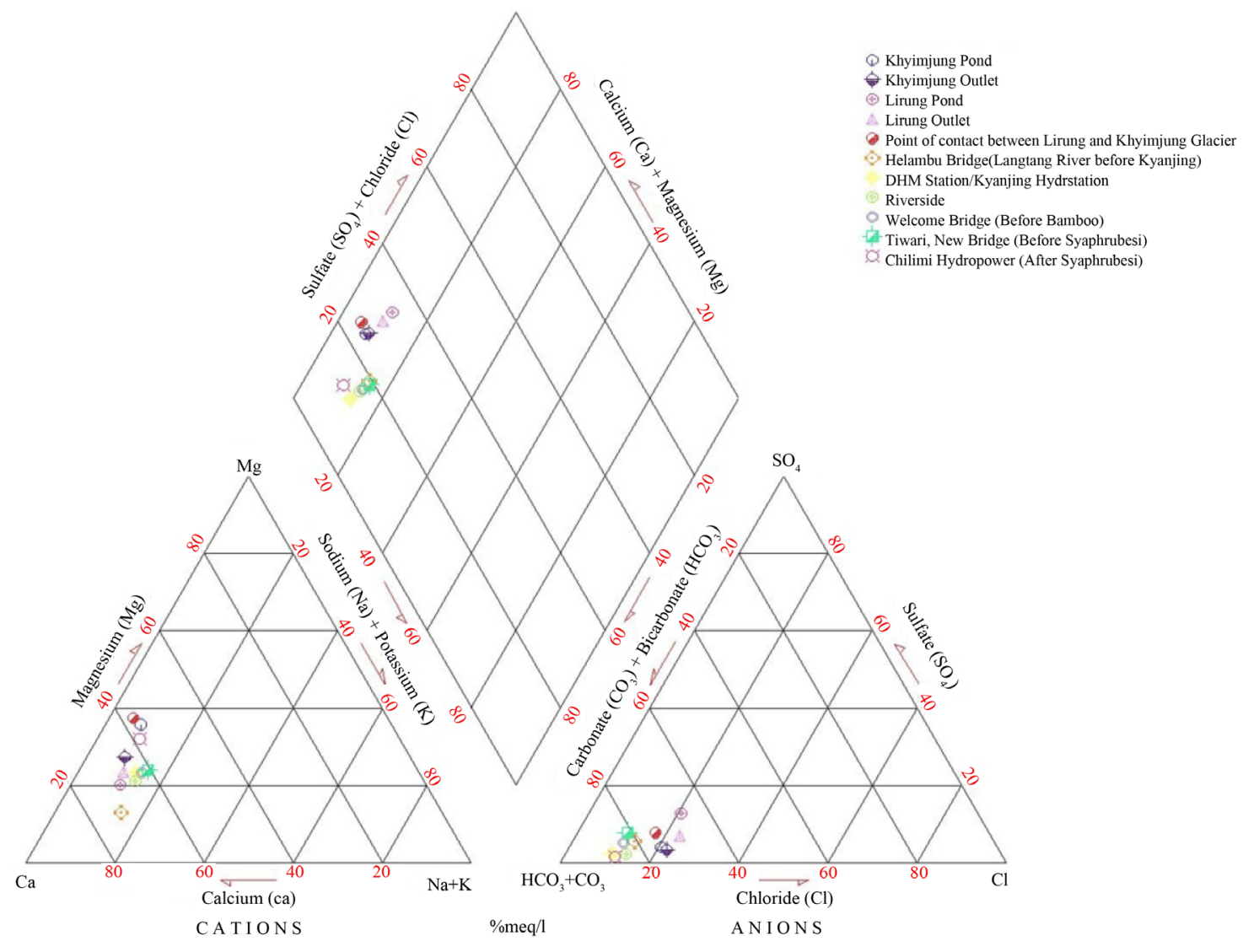

Figure 3. Piper plot diagram of melt waters draining from langtang valley. 
and anion respectively. The Pearson's $r$ value shows that calcium has positive significant $(\mathrm{p}<0.05)$ relationship with bicarbonate. These results confirm that the calcium carbonate weathering is the major source of dissolved ions in the region. Correlations among the divalent cations and $\mathrm{HCO}_{3}$ probably reflect common geologic sources [24] of these ions.

The elemental ratios of the Langtang Valley are given in the Table 3 . The average $\mathrm{Ca} / \mathrm{Si}$ ratio is postulated to be higher in glacial waters due to preferential weathering of carbonates and slow weathering of silicates [25]. Also, the average K/Na ratio is suggested to be distinctly higher than non-glacial runoff due to preferential weathering of K-mica minerals, resulting in high $\mathrm{K}$ concentrations [26]. The importance of atmospheric input for river water composition can also be determined by the ratio of ions to chloride. The average $\mathrm{Na} / \mathrm{Cl}$ and $\mathrm{K} / \mathrm{Cl}$ ratio were close to that of sea water (i.e., $\mathrm{Na} / \mathrm{Cl}=1.0$ and $\mathrm{K} / \mathrm{Cl}=0.2$ respectively). These ratios indicated major contribution from atmospheric precipitation to the observed dissolved ions of melt waters.

The relative importance of two major proton producing reactions-carbonation and sulphide oxidation can be evaluated on the basis of the C-ratio $\left(\mathrm{HCO}_{3} / \mathrm{HCO}_{3}+\mathrm{SO}_{4}\right)$. The Carbon ratio is closer to 1 , which indicates the significance of carbonation reaction involving acid hydrolysis and pure dissolution, consuming protons from atmospheric $\mathrm{CO}_{2}$ [27] (Equations (1)-(3)). Conversely if $\mathrm{C}$ ratio is 0.5 , it would suggest coupled reaction involving carbonate weathering and protons derived from oxidation of sulphide [27].

$$
\begin{gathered}
\mathrm{CO}_{2}+\mathrm{H}_{2} \mathrm{O} \leftrightarrow \mathrm{H}_{2} \mathrm{CO}_{3} \\
\mathrm{H}_{2} \mathrm{CO}_{3} \leftrightarrow \mathrm{H}^{+}+\mathrm{HCO}_{3}^{-} \\
\mathrm{CaCO}_{3}(\mathrm{~s})+\mathrm{H}_{2} \mathrm{CO}_{3} *(\mathrm{aq}) \rightarrow \mathrm{Ca}^{2+}(\mathrm{aq})+2 \mathrm{HCO}_{3}^{-}(\mathrm{aq})
\end{gathered}
$$

where (g), (1), (aq), and (s) denote gaseous, liquid, aqueous and solid phases respectively.

In general, concentration of major cations (particularly $\mathrm{Ca}$ ), anions $\left(\mathrm{NO}_{3}\right.$ and $\left.\mathrm{TP}-\mathrm{PO}_{4}\right)$ and total silica showed an increasing trend (Figure 4 and Figure 5) compared to the previous studies [18] [19]. It may be due to increase in chemical weathering from temperature increase in the basin since the rates of chemical weathering mainly depend on temperature [29] [30]. Moreover, the maximum temperature in the Nepal Himalayas has been shown to increase by at least $0.06^{\circ} \mathrm{C}$ per year [28].

\begin{tabular}{cccccc} 
Table 3. Elemental ratios. & \multicolumn{1}{l}{} \\
\hline & $\mathrm{Ca} / \mathrm{Si}$ & $\mathrm{K} / \mathrm{Na}$ & $\mathrm{Na} / \mathrm{Cl}$ & $\mathrm{K} / \mathrm{Cl}$ & $\mathrm{C}$ ratio \\
\hline Average & 2.26 & 1.20 & 0.23 & 0.26 & 0.84 \\
$\mathrm{SD}$ & 0.73 & 0.33 & 0.12 & 0.13 & 0.09 \\
Min & 1.40 & 0.53 & 0.07 & 0.11 & 0.65 \\
Max & 4.06 & 1.85 & 0.41 & 0.46 & 0.95 \\
\hline
\end{tabular}

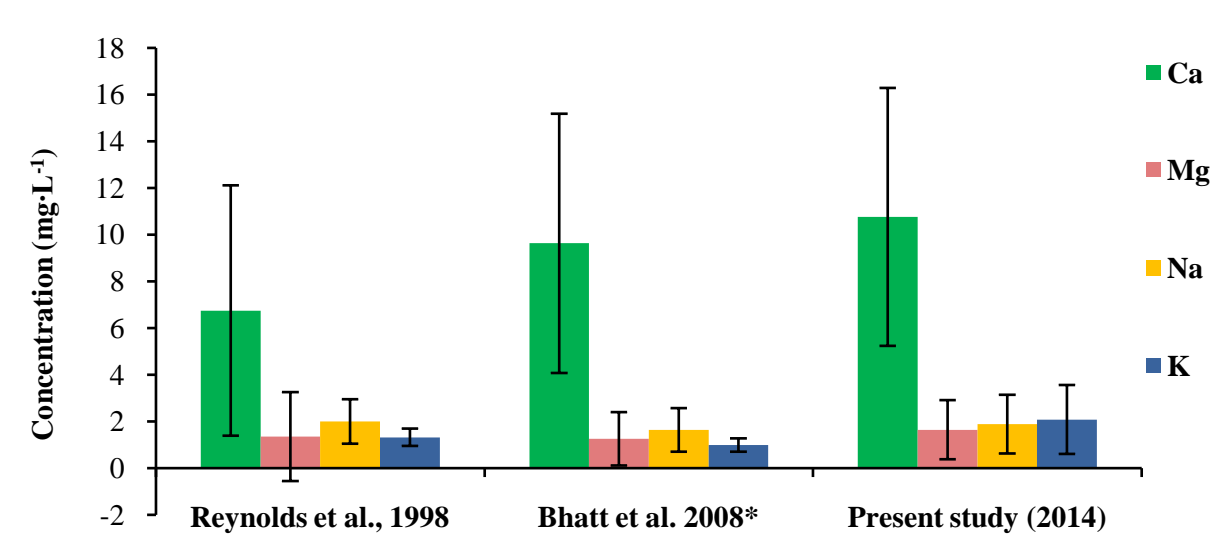

*Note: Sampling taken in 1996 
The $\mathrm{NO}_{3}$ and $\mathrm{TP}-\mathrm{PO}_{4}$ concentration were higher in monsoon season than pre-monsoon. Nutrients, such as nitrogen and phosphorus, are supplied onto the glacier surface by dry and wet depositions [31]. The comparatively variable concentration of $\mathrm{NO}_{3}$ may be due to a larger atmospheric deposition in the higher altitude as findings of the similar studies done by [19]. Other sources of $\mathrm{NO}_{3}$ and $\mathrm{TP}-\mathrm{PO}_{4}$ may arise from human impacts.

The chemical characteristics of melt water draining from the Khimsung and Lirung glacier of Langtang valley are given in Table 4. The average concentrations of most of the cations and anions were comparatively higher in Lirung Glacier than Khimsung Glacier. This suggests that the contact time of melt water with sediment beneath the glacier and rate of weathering of Lirung Glacier is higher compared to Khimsung glacier, resulting in higher solute concentration. Moreover, with higher catchment size and area covered by the glacier, the debris cover in the Lirung Glacier [14] [32] could provide more interaction of solutes with water thereby resulting in rapid dissolution.
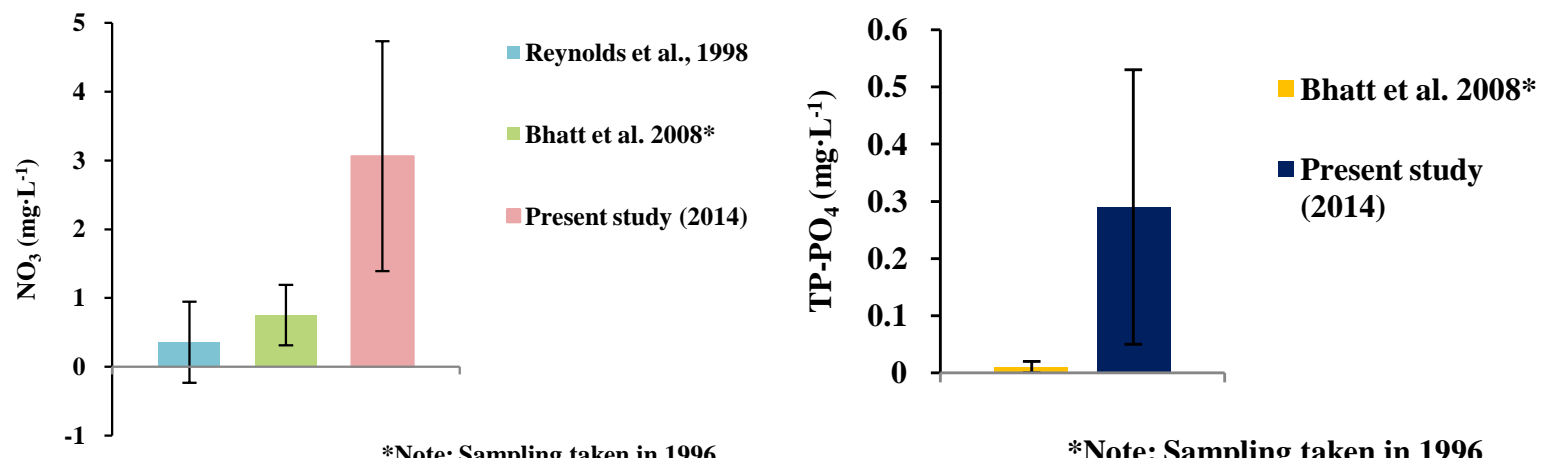

*Note: Sampling taken in 1996

*Note: Sampling taken in 1996

Figure 5. Temporal variation of nitrate and total phosphorus.

Table 4. Average meltwater chemical concentrations of the khimsung and the lirung glacier.

\begin{tabular}{|c|c|c|c|c|c|c|c|c|c|}
\hline \multicolumn{4}{|c|}{ Khimsung Glacier } & \multicolumn{6}{|c|}{ Lirung Glacier } \\
\hline Parameter & Unit & Max & Min & Average & SD & Max & Min & Average & SD \\
\hline $\mathrm{pH}$ & - & 8.60 & 7.50 & 7.90 & 0.29 & 8.50 & 7.70 & 8.07 & 0.22 \\
\hline EC & $\mu \mathrm{S} \cdot \mathrm{cm}^{-1}$ & 45.00 & 8.00 & 25.08 & 14.76 & 79.00 & 20.00 & 51.67 & 28.09 \\
\hline TDS & ppm & 18.00 & 4.00 & 10.58 & 5.58 & 35.00 & 11.00 & 23.00 & 11.07 \\
\hline DO & $\mathrm{mg} / \mathrm{l}$ & 9.50 & 8.40 & 8.82 & 0.37 & 9.80 & 7.21 & 8.76 & 1.02 \\
\hline Turbidity & NTU & 41.70 & 12.50 & 23.63 & 11.74 & 20.00 & 11.00 & 15.74 & 2.94 \\
\hline TSS & $\mathrm{mg} \cdot \mathrm{L}^{-1}$ & 180.00 & 34.00 & 108.50 & 60.19 & 80.00 & 18.00 & 40.00 & 28.33 \\
\hline $\mathrm{Ca}^{2+}$ & $\mathrm{mg} \cdot \mathrm{L}^{-1}$ & 9.20 & 2.24 & 5.66 & 3.45 & 15.50 & 2.40 & 8.66 & 6.85 \\
\hline $\mathrm{Mg}^{2+}$ & $\mathrm{mg} \cdot \mathrm{L}^{-1}$ & 1.98 & 0.44 & 1.10 & 0.67 & 1.75 & 0.50 & 1.08 & 0.62 \\
\hline $\mathrm{Na}^{+}$ & $\mathrm{mg} \cdot \mathrm{L}^{-1}$ & 0.80 & 0.50 & 0.68 & 0.15 & 2.00 & 0.60 & 1.25 & 0.70 \\
\hline $\mathrm{K}^{+}$ & $\mathrm{mg} \cdot \mathrm{L}^{-1}$ & 1.40 & 0.80 & 1.03 & 0.26 & 2.60 & 0.80 & 1.58 & 0.83 \\
\hline $\mathrm{HCO}_{3}^{-}$ & $\mathrm{mg} \cdot \mathrm{L}^{-1}$ & 36.60 & 12.93 & 24.89 & 13.53 & 29.30 & 18.79 & 24.11 & 6.00 \\
\hline $\mathrm{CO}_{3}^{2-}$ & $\mathrm{mg} \cdot \mathrm{L}^{-1}$ & 18.00 & 6.36 & 12.24 & 6.65 & 14.40 & 9.23 & 11.85 & 2.95 \\
\hline $\mathrm{SO}_{4}^{2-}$ & $\mathrm{mg} \cdot \mathrm{L}^{-1}$ & 5.00 & 0.40 & 2.45 & 2.40 & 19.00 & 1.20 & 7.65 & 8.39 \\
\hline $\mathrm{Cl}^{-}$ & $\mathrm{mg} \cdot \mathrm{L}^{-1}$ & 11.00 & 5.00 & 8.50 & 2.65 & 12.00 & 7.00 & 9.25 & 2.63 \\
\hline $\mathrm{NO}_{3}^{-}$ & $\mathrm{mg} \cdot \mathrm{L}^{-1}$ & 2.60 & 2.30 & 2.45 & 0.21 & 7.50 & 3.40 & 5.45 & 2.90 \\
\hline TP- $\mathrm{PO}_{4}^{3-}$ & $\mathrm{mg} \cdot \mathrm{L}^{-1}$ & 0.20 & 0.06 & 0.12 & 0.07 & 0.50 & 0.09 & 0.30 & 0.29 \\
\hline $\mathrm{Si}$ & $\mathrm{mg} \cdot \mathrm{L}^{-1}$ & 4.00 & 1.80 & 2.60 & 1.22 & 9.30 & 2.50 & 4.65 & 3.18 \\
\hline $\mathrm{Fe}$ & $\mathrm{mg} \cdot \mathrm{L}^{-1}$ & 5.20 & 3.00 & 4.05 & 1.22 & 7.20 & 2.20 & 3.88 & 2.27 \\
\hline Mn & $\mathrm{mg} \cdot \mathrm{L}^{-1}$ & 0.06 & 0.05 & 0.06 & 0.01 & 0.08 & 0.08 & 0.08 & - \\
\hline $\mathrm{Al}$ & $\mathrm{mg} \cdot \mathrm{L}^{-1}$ & 0.07 & 0.07 & 0.07 & - & 0.20 & 0.20 & 0.20 & - \\
\hline
\end{tabular}




\section{Conclusion}

Hydro-chemistry of glacial melt waters of the Langtang Valley was studied. The alkaline nature of pH, high DO, variable TSS and Turbidity were seen typical of the headwaters. Calcium and bicarbonate ions were the dominant cation and anion respectively. Calcium carbonate weathering was the major source of dissolved ions in the region. There has been an increase in the concentration of cations from the past few years, which may be due to increase in chemical weathering due to temperature increase in the basin. Elevated concentration of nitrates and total phosphates are seen compared to previous studies, the effect of human impact in the region. The elemental ratios $(\mathrm{Ca} / \mathrm{Si}$ and $\mathrm{K} / \mathrm{Na}$ ) were typical of glacial melt water and the low $\mathrm{Na} / \mathrm{Cl}$ and $\mathrm{K} / \mathrm{Cl}$ ratios indicated major contribution from atmospheric precipitation to the observed dissolved ions of melt waters. Carbonation reaction involving acid hydrolysis and pure dissolution, consuming protons from atmospheric $\mathrm{CO}_{2}$ were the main proton supplying geochemical reactions controlling the rock weathering in the study area. The average concentrations of most of the cations and anions were comparatively higher in Lirung Glacier than Khimsung Glacier.

\section{Acknowledgements}

We are very grateful to the Partnership for Enhanced Engagement in Research (PEER) Science Project funded by the United States Agency for International Development (USAID) through the National Science Foundation (NSF), USA for supporting this research. We are also thankful to the Department of National Park and Wild Life Conservation, GoN and all the members of Himalayan Cryosphere, Climate and Disaster Research Center, Kathmandu University for their kind cooperation while conducting this research.

\section{References}

[1] Barry, R. and Seimon, A. (2000) Research for Mountain Area Development: Climatic Fluctuations in the Mountains of the Americas and Their Significance. Ambio, 364-370.

[2] Jansson, P., Hock, R. and Schneider, T. (2003) The Concept of Glacier Storage: A Review. Journal of Hydrology, 116-129. http://dx.doi.org/10.1016/S0022-1694(03)00258-0

[3] Schaner, N., Voisin, N. and Nijssen, B. (2012) The Contributions of Glacier Melt to Streamflow. Environmental Research Letters, 7, 034029. http://dx.doi.org/10.1088/1748-9326/7/3/034029

[4] Kaser, G., Groshauser, M. and Marzeion, B. (2010) Contributionpotential of Glaciers to Water Availability Indifferent Climate Regimes. Proceedings of the NationalAcademy of Sciences, 107, 20223-20227.

[5] Viviroli, D., Archer, D.R. and Buytaert, W. (2011) Climate Change and Mountain Water Resources: Overview and Recommendations for Research, Management and Policy. Hydrology and Earth System Sciences, 15, 471-504. http://dx.doi.org/10.5194/hess-15-471-2011

[6] ICIMOD (2011) Report on the Impact of Climate Change on Water Resources and Livelihoods in the Himalayas.

[7] Bhatt, M.P., Masuzawa, T., Yamamoto, M., Sakai, A. and Fujita, K. (2000) Seasonal Changes in Dissolved Chemical Composition and Flux of Melt Water Draining from Lirung Glacier in the Nepal Himalayas. Proceedings of a Workshop on Debris-Coved Glaciers, Seattle, IAHS Publ. No. 264, 277-288.

[8] WECS (2011) Water Resources of Nepal in the Context of Climate Change. Water and Energy Commission Secretariat (WECS). www.wec.gov.np

[9] IPCC (2007) IPCC Fourth Assessment Report. Climate Change, Working Group II: Impacts, Adaptation and Vulnerability.

[10] Moore, R.D. (2009) Glacier Change in Western North America: Influences on Hydrology, Geomorphic Hazards and Water Quality. Hydrological Process, 23, 42-61. http://dx.doi.org/10.1002/hyp.7162

[11] Ghimire, N.P., Jha, P.K. and Caravello, G. (2013) Physico-Chemical Parameters of High-Altitude Rivers in the Sagarmatha (Everest) National Park, Nepal. Journal of Water Resource and Protection, 5, 761-767. http://dx.doi.org/10.4236/jwarp.2013.58077

[12] Singh, V.B., Ramanathan, A.L., Pottakkal, J.G., Sharma, P., Linda, A., Azam, M.F. and Chatterjee, C. (2012) Chemical Characterisation of Meltwater Draining from Gangotri Glacier, Garhwal Himalaya, India. Journal of Earth System Science, 121, 625-636. http://dx.doi.org/10.1007/s12040-012-0177-7

[13] Asahi, K. (1997) Glacier Inventory of the Eastern Part of Nepal Himalayas. Proceedings of the General Meeting of the Association of Japanese Geographers, 52, 242-243. (In Japanese)

[14] Fukushima, Y., Kawashima, K., Suzuki, M., Ohta, T., Motoyama, H., Kubota, H. and Bajracharya, O.R. (1987) The Hydrological Data of Langtang Valley, Nepal Himalayas. Bulletin of Glacier Research, 5, 11-18. 
[15] APHA, AWWA and WPCF (1999) Standard Methods for the Examination of Water and Wastewater. 20th Edition, American Public Health Association, Washington DC.

[16] Piper, A.M. (1994) A Graphical Procedure in the Geochemical Interpretation of Water Analysis. Transactions, American Geophysical Union, 25, 914-923. http://dx.doi.org/10.1029/TR025i006p00914

[17] Freeza, R.A. and Cherry, J.A. (1979) Groundwater. Prentice-Hall Inc., Englewood Cliffs.

[18] Bhatt, M.P., Masuzawa, T., Yamamoto, M. and Gardner, K.H. (2008) Spatial Variations in Chemical Compositions along Langtang-Narayani River System in Central Nepal. Environmental Geology, 57, 557-569. http://dx.doi.org/10.1007/s00254-008-1325-X

[19] Reynolds, B., Jenkins, A., Chapman, P.J. and Wilkinson, J. (1998) Stream Hydrochemistry of the Khumbu, Annapurna and Langtang Regions of Nepal. In: Baudo, R., Tartari, G. and Munawar, M., Eds., Top of the World Environmental Research: Mount Everest-Himalayan Ecosystem, Backhuys Publishers, Leiden, 123-141.

[20] Murphy, S.F. (2007) General Information on Dissolved Oxygen. City of Boulder/USGS Water Quality Monitoring. http://bcn.boulder.co.us/basin/main/SFM.html

[21] Halloy, S. (1989) Altitudinal Limits of Life in Subtropical Mountains: What Do We Know? Pacific Science, 43, 170184.

[22] Navas, C.A. (2003) Herpetological Diversity along Andean Elevational Gradients: Links with Physiological Ecology and Evolutionary Physiology. Comparative Biochemistry and Physiology Part A, 133, 469-485. http://dx.doi.org/10.1016/S1095-6433(02)00207-6

[23] Garrels, R.M. and Mackenzie, F.T. (1971) Evolution of Sedimentary Rocks. W. W. Norton \& Company, New York, $450 \mathrm{p}$.

[24] Saunders, J.F. and Lewis, W.M. (1989) Transport of Major Solutes and the Relationship between Solute Concentrations and Discharge in the Apure River, Venezuela. Biogeochemistry, 8, 101-113. http://dx.doi.org/10.1007/BF00001315

[25] Tranter, M., Brown, G.H., Sharp, M.J. and Gurnell, A.M. (1993) A Conceptual Model of Solute Acquisition by Alpine Glacial Meltwaters. Journal of Glaciology, 39, 573-581.

[26] Anderson, S.P., Drever, J.I. and Humphrey, N.F. (1997) Chemical Weathering in Glacial Environments. Geology, 25, 399-402. http://dx.doi.org/10.1130/0091-7613(1997)025<0399:CWIGE >2.3.CO;2

[27] Brown, G.H., Tramter, M. and Sharp, M. (1996) Subglacial Chemical Erosion-Seasonal Variations in Solute Provenance, Haut Glacier d'Arolla, Switzerland. Annals of Glaciology, 22, 25-31.

[28] Shrestha, A.B., Wake, C.P., Dibb, J.E. and Mayewski, P.A. (1999) Maximum Temperature Trends in the Himalaya and Its Vicinity: An Analysis Based on Temperature Records from Nepal for the Period 1971-94. Journal of Climate, 12, 2775-2786.

[29] Brady, P.V. and Carrol, S.A. (1994) Direct Effects of $\mathrm{CO}_{2}$ and Temperature on Silicate Weathering: Possible Implications for Climate Control. Geochimica et Cosmochimica Acta, 58, 1853-1856. http://dx.doi.org/10.1016/0016-7037(94)90543-6

[30] Lami, A., Marchetto, A., Musazzi, S., Salerno, F., Tartari, G., Guilizzoni, P., Rogora, M. and Tartari, G.A. (2010) Chemical and Biological Response of Two Small Lakes. Hydrobiologia, 648, 189-205.

[31] Takeuchi, N. (2011) Glacial Ecosystems. In: Singh, V.P., Singh, P. and Haritashya, U.K., Eds., Encyclopedia of Snow, Ice and Glaciers, Springer, Dordrecht, 330-331.

[32] Kohshima, S., Seko, K. and Yoshimura, Y. (1993) Biotic Acceleration of Glacier Melting in Yala Glacier, Langtang Region, Nepal Himalaya. In: Young, G.J., Ed., Snow and Glacier Hydrology, IAHS Publication No. 218, 309-316. 